\title{
Pursuing PhD by publication in geography: a collaborative autoethnography of two African doctoral researchers
}

\section{Lewis Abedi Asante \& Zaid Abubakari}

To cite this article: Lewis Abedi Asante \& Zaid Abubakari (2021) Pursuing PhD by publication in geography: a collaborative autoethnography of two African doctoral researchers, Journal of Geography in Higher Education, 45:1, 87-107, DOI: 10.1080/03098265.2020.1803817

To link to this article: https://doi.org/10.1080/03098265.2020.1803817

曲 Published online: 10 Aug 2020.

Submit your article to this journal $₫$

LII Article views: 289

Q View related articles 5

View Crossmark data $₫$

Citing articles: 1 View citing articles ¿ð 


\title{
Pursuing PhD by publication in geography: a collaborative autoethnography of two African doctoral researchers
}

\author{
Lewis Abedi Asante (iD) and Zaid Abubakarib
}

aDepartment of Estate Management, Faculty of Built and Natural Environment, Kumasi Technical University, Kumasi, Ghana; ${ }^{b}$ Faculty of Geo-Information Science and Earth Observation, University of Twente, Enschede, The Netherlands

\begin{abstract}
Several scholars have, over the years, written about their experiences of the pathway of PhD by publication (PBP). However, little is known about why African doctoral students pursue PBP and their experiences. In this article, we adopt collaborative autoethnography to document our experiences and motivation for choosing the PBP pathway. Based on our experiences, the choice of PBP is primarily influenced by the candidate's previous research experience and the requirements/practices of the university. The common motivation among African doctoral students is the quest to acquire the requisite research skills and training in journal article publishing and the determination to catch-up in the knowledge economy through the production of high-quality scientific publication. Everyday experiences of PBP are shaped by university expectations, scholarly writing skills, institutional, supervisory and external support systems, research training and resilience. This study concludes by highlighting the positive implications of PBP for educational and socio-economic development in Africa and the world, more generally. It is recommended that journals develop scholar development programs to enable their editors to provide individualized support to PhD students, especially those pursuing PBP.
\end{abstract}

\section{ARTICLE HISTORY}

Received 25 March 2020

Accepted 16 June 2020

\section{KEYWORDS}

$\mathrm{PhD}$ by publication; experiences; motivation; African doctoral researchers; collaborative autoethnography

\section{Introduction}

It is argued that the continuous pressure to tie the outcomes of doctoral research to the assessment of research quality and productivity is changing, and intensifying the climate of doctoral education around the globe (Frick, 2016; Horta \& Santos, 2016; Lee \& Kamler, 2008; Niven \& Grant, 2012; Watts, 2012). Consequently, PhD by publication (PBP) has emerged in many disciplines as a contemporary alternative pathway of doctoral research that responds effectively to the new academic realities and expectations. Nevertheless, it is argued that PBP is more desirable in the natural and biomedical sciences than in the social sciences and humanities (Mason, 2018; Niven \& Grant, 2012). Structurally, students who take this pathway produce a kind of doctoral dissertation that comprises of individual but logically coherent refereed and published or accepted articles written during the period of the doctoral research, usually accompanied by an overarching 
introductory and concluding chapters (Connor, 2016; Lee, 2010; Robins \& Kanowski, 2008). The PBP pathway is gaining prominence in many universities, as publications are increasingly being used as a measure of institutional performance, as well as a key criterion in academic promotion, university ranking and research funding (Asongu \& Nwachukwu, 2018; Carr \& Hayes, 2017; Davies \& Rolfe, 2009; Frick, 2019; Kamler, 2008; Mason, 2018; Merga et al., 2019; O'Keeffe, 2020). The increasing popularity of the PBP pathway cuts across different academic fields. For instance, Dowling et al. (2012) indicate that over $30 \%$ of all $\mathrm{PhDs}$ submitted at the human geography department at Macquarie University in Australia take the PBP pathway.

Although the PBP pathway is gaining prominence, it is not without shortcomings. It has suffered a barrage of criticisms from scholars in terms of logical coherence of research output, intellectual contribution, ambiguity of interests and time pressure (Jackson, 2013; Robins \& Kanowski, 2008). Firstly, it is argued that the individual chapters (or articles) in the publication-based dissertations lack coherence and often do not have relevant logical connections between them. This is because addressing reviewer comments often entails a compromise as it involves a counter-weighting of opposing views. As such, the direction and aims of original manuscripts can sometimes change considerably through the comments of reviewers in the article review process (Pretorius, 2017). Secondly, there is the argument that the intellectual input of the doctoral student to the published articles is often not apparent (Sharmini et al., 2015). Thirdly, it is not clear whose interest the PBP pathway serves. This is especially the case when the PBP pathway is made mandatory and candidates are required to publish before completion. Given that publications play a role in the ranking of scholars and academic institutions, it becomes unclear whether the mandatory requirement for PBP is meant to fulfill the supervisor's academic credentials, the students' scholarly development or even the university's ranking (Frick, 2019). This is really important to clarify as the hidden interests can inflict enormous pain and stress on $\mathrm{PhD}$ candidates. Lastly, the turnaround time for the process of peer-review is getting longer, as many journals have emerged and more manuscripts are submitted, yet journals resort to similar cohort of experienced reviewers. This has the potential to impact the ability of a doctoral student to complete the thesis in a timely manner (Mason, 2018). As a result, there is resistance and reluctance among some students, supervisors and examiners to the PBP. Some scholars consider it either an "easy-way-out" to the doctoral qualification (Niven \& Grant, 2012, p. 106), or not taken as seriously as "real" PhDs (Mason, 2018). Even at the level of $\mathrm{PhD}$ thesis examination, some examiners still consider the individual published articles of the thesis as unpublished or work in progress, and could demand students to make changes on published chapters (Sharmini \& Kumar, 2018).

Despite the shortfalls of the PBP pathway, Dowling et al. (2012) argue that the PBP pathway has evolved to address many of its associated criticisms. For example, Niven and Grant (2012) have argued that the problem of thesis incoherence is addressed in the introductory and concluding chapters of the PBP, where doctoral students work backward and forward to develop a logic of connectivity at both the theoretical and methodological levels. Also concerning intellectual input, several universities require doctoral students to be the main author or must have contributed significantly to all articles in the thesis. Guidelines are also provided for doctoral students to provide a written explanation in the thesis of their contribution to any co-authored publications (Sharmini et al., 2015). 
As the PBP pathway evolves, its benefits are increasingly being observed in the training of doctoral students.

Studies show that doctoral researchers who undertake the PBP pathway demonstrate skills in developing a journal article and the tenacity to navigate the painstaking peerreview process (Davies \& Rolfe, 2009; Jackson, 2013). By so doing, prior to completing their degrees, these doctoral researchers consolidate a research profile, build scientific credibility and display their readiness for a career in the highly competitive academic or research job market (Asongu \& Nwachukwu, 2018; Niven \& Grant, 2012). A recent study by Horta and Santos (2016) has shown that individuals who publish during the PhD have greater research production and productivity, and greater numbers of yearly citations throughout their academic career than those who do not publish during their $\mathrm{PhD}$. Scholars also contend that the pathway of PBP disseminates new research that contributes to the global knowledge economy while driving innovation at the local level (Jackson, 2013). It also offers doctoral candidates, in contemporary academia, performance incentive and a means by which the scientific knowledge gap between developed and developing countries can be reduced (Asongu \& Nwachukwu, 2018).

For the field of geography, Dowling et al. (2012) argued that there is a relative lack of attention paid within human geography to the processes and characteristics of doctoral education, and even less theorization of research supervision. This argument adds to the justification of our study to characterize our experiences in the field of geography. For students on the PBP, the interdisciplinary nature of geography affords a very good opportunity to make intellectual linkages between different aspects of geography and related fields, although Sigler et al. (2018) argued that the interdisciplinarity makes the field of geography susceptible to dilution. We however contend that the PBP pathway is an enabling factor to stir cutting edge research in geography, just like other fields of study. PBP in geography thus enables the sharing of context-specific insights, which help to fine-tune generalized global discourses for inter-subjective acceptability (Eigi, 2013).

In recent years, Amavilah (2009) has demonstrated that, while there has been progress in knowledge production of African countries measured in terms of doctoral dissertation, the rate of the progress has been significantly slow. A considerable number of doctoral dissertations in African universities or those conducted by African students in Western universities remain as "unpublished thesis". As indicated by Kamler (2008), when the results of doctoral research are not published, there is a limited opportunity for such knowledge to advance a field and the socio-economic development of the country or region where it was conducted. More so, the number of publications on Africa that appears in international journals are few compared to other parts of the world (Asongu \& Nwachukwu, 2018). This is largely because the majority of the rejected manuscripts by international journals are submitted by African scholars (Tarkang \& Bain, 2019). Even in journals dedicated to Africa, a chunk of the knowledge production is conducted by nonAfricans. It is therefore unsurprising that only $2 \%$ of the world research output are produced by African researchers (Tarkang \& Bain, 2019). This snail pace of knowledge production by Africans has undermined the socio-economic performance of many African countries (Amavilah, 2009). This is because there is a direct link between knowledge production and economic wealth and growth of a country or continent (Gumbo, 2017). Asongu and Nwachukwu (2018) have argued, in a recent study, that PBP has the potential to expand the base and to quicken the pace of knowledge 
production on African countries. They further indicated that, for African-based doctoral research to become useful to the larger society, they must be harmonized with publication in top-tier journals in order to enhance technology and innovation transfer that are vital in improving the design and quality of existing and new products. For African geographers, the PBP is even more crucial for us to have a strong voice on vexed issues such as urban and land governance, urban development and planning, land use planning and administration, climate change and resource management among others.

A review of the existing literature shows that there is a growing body of knowledge on PBP. Most of the literature examine the nature of PBP in universities across the world and seek to offer a robust understanding of this mode of doctoral research (e.g. Asongu \& Nwachukwu, 2018; Connor, 2016; Frick, 2019; Jackson, 2013; Lee, 2010; O’Keeffe, 2020; Peacock, 2017). Others have focused on exploring how PBP takes forward the field of doctoral researchers (Davies \& Rolfe, 2009; Horta \& Santos, 2016; Lee \& Kamler, 2008). We have also seen studies on students, supervisors and examiners sharing their perspective on the strengths and limitations of PBP (Merga, 2015; Niven \& Grant, 2012; Robins \& Kanowski, 2008; Sharmini \& Kumar, 2018; Sharmini et al., 2015). In recent years, Africans have also joined the discussion, revealing PBP as a tool for innovation and technology transfer (Asongu \& Nwachukwu, 2018). In this study, we pose the questions: What is the source of motivation for African doctoral students who choose the PBP pathway? What are their everyday experiences towards successful completion of their publication-based dissertation?

Through a collaborative autoethnographic approach, we demonstrate that the determinants of the choice of PBP pathway are the student's pre-doctoral research experience and the nature of one's $\mathrm{PhD}$ positions. We are motivated by the fact that the PBP pathway makes knowledge production of the African continent significantly visible, thereby enhancing the image of African universities. Having together published seven out of nine articles in our $\mathrm{PhD}$ dissertation in top-rated geography journals, our experiences of writing PBP were shaped by university expectations, nurturing scholarly writing skills, institutional and supervisory support systems, intensive research training and developing resilience in research publication. This article does not only highlight our motivation and experiences of producing PBP in Geography, but also demonstrates how this pathway has enabled us to contribute immensely to knowledge production in Ghana and Africa more broadly. The rest of the article is organized as follows. The next section reviews the literature on doctoral students' experiences of PBP. In Section three, we describe the research method. This is followed in Section four by the profile, motivation and experiences of the authors. Section five focuses on the discussion. The study is concluded in Section six.

\section{Conceptualizing doctoral students' experiences of PhD by publication}

This study conceptualizes the experiences of doctoral students who are at different stages of doing their $\mathrm{PhD}$ studies. Previous studies generally agree on the fact that doctoral students require certain skills, support and knowledge to successfully complete a PBP (Jackson, 2013; Merga, 2015; Merga et al., 2019; Urda-Cîmpean et al., 2016). According to Merga (2015), these include understanding university expectations, confidence in writing, institutional and supervisory support, a selective approach to skills acquisition 
during doctoral candidacy, and resilience. Similarly, Jackson (2013, p. 365) has argued that 'a certain kind of personality is required for this pathway: excellent time management skills, strong writing capabilities, an understanding of current literature (or willingness and ability to grasp this in the initial months of candidature) and perseverance'. In the next paragraphs, these factors are discussed.

To start with, doctoral students must understand the expectations and requirements of their chosen university prior to considering whether the PBP is an appropriate strategy that is achievable within a certain timeframe (Mason, 2018; Merga, 2015). Generally, students are expected to produce a certain number of articles, out of which some must be published or accepted with revision, while the others may only be submitted. Mason (2018) for instance indicated that her thesis was planned to comprise of 6 papers. However, her university - Griffith University in Australia - required a minimum of one published paper at the time of submission, while other papers were allowed to be inpress or submitted for review. She argued that such a requirement alleviates the stress that may otherwise have been felt if she was required to have published all six papers. Other universities may have more burdensome requirements for PBP. Pretorius (2017) reported that some departments in the University of Pretoria, South Africa, require students to publish five articles in top-tier journals prior to submission. Frick (2016) and Pretorius (2017) indicated that this may be the case in South Africa because the promotion of professors and their eligibility for funding is inherently tied to a peer evaluation - the National Research Foundation rating - which considers research publications' impact, postgraduate student supervision (particularly $\mathrm{PhD}$ students) and the level of competency within the field of expertise. In PBP, articles are normally based on minor, but inter-related, research questions, which connect to a major one. Some universities allow co-authored papers to be included in the dissertation but clearly indicate that the student should have made a significant contribution and should preferably be the first author (Jackson, 2013). A few universities expect students to be the sole author of most of the articles in their dissertation. Aside from the articles, most universities expect the journal articles to be accompanied by introductory and concluding chapters when compiling the thesis (Merga, 2015; Pretorius, 2017; Robins \& Kanowski, 2008).

Secondly, doctoral students bring with them different personal skills and characteristics to the research endeavor (Merga et al., 2019; Robins \& Kanowski, 2008). One such personal skill is a good scholarly writing ability. It is argued that the confidence in scholarly writing has to be fostered early if a doctoral student wishing to write PBP dissertation does not already possess it (Merga, 2015). For doctoral students who already have strong scholarly writing skills, the PBP is a more flexible pathway to completing their studies. In the United Kingdom, Smith (2017, p. 29) noted that a considerable number of the doctoral students who pursue PBP are established researchers known in their field, but who may not have had the opportunity to undertake a doctorate. This group of students develop their writing skills from previous experience of publishing in top-rated journals (Niven \& Grant, 2012; Smith, 2017). For other students, the writing skill is gained from previous work activities that involved regular report writing. It is also possible for some doctoral students to acquire such skills early in their candidature through regular reading of scholarly works, as well as institutional and supervisory support. 
Thirdly, most doctoral students who successfully completed PBP had good institutional and supervisory support (Jackson, 2013; Merga, 2015; Robins \& Kanowski, 2008). To start with institutional support, many students develop or sharpen their writing skills at university centres or programs that teach academic writing. In some universities, workshops or seminars are organized to educate doctoral students about all that they need to know about the PBP pathway. Some students also developed personal institutional networks that provide feedback on their articles prior to submission. In some departments, there is the opportunity for students to present their draft papers at work-in -progress seminars or colloquiums (Lee, 2010). Aside from institutional support, the experience of Robins and Kanowski (2008, p. 17) shows that "the active support of supervisors is central to enabling publication by doctoral students, and to its fuller expression in a strategy of pursuing $\mathrm{PhD}$ by publication". Although most universities and departments are promoting PBP and providing students with the needed assistance, some supervisors remain opposed to this doctoral pathway. Consequently, scholars have suggested that doctoral students considering PBP should find out the perspectives of potential supervisors, and should consider changing supervisors if opposing views about PBP cannot be resolved (Robins \& Kanowski, 2008; Sharmini et al., 2015). This is very important, because supervisors who are opposed to PBP may not provide students with the support they need to complete their studies. However, supervisors who are positive about PBP provide support such as guiding students to design their research with separable but logically coherent publishable elements, providing them with timely and critical pre-submission feedback and co-authoring articles with them. In this sense, the success of the doctoral candidate in publishing also promotes the publication trajectory of the supervisor.

Furthermore, studies have indicated that doctoral students who take the PBP pathway consider the $\mathrm{PhD}$ process as a research training or apprenticeship that would culminate in the doctoral qualification (Merga, 2015; Urda-Cîmpean et al., 2016). They contend that a monograph writing skill is not likely to be repeatedly utilized. In fact, this skill may have been acquired by many students during the masters programme. Therefore, some students consider journal article writing and negotiating the process of submission and response to reviewers as a more valuable research training and skill to acquire during doctoral studies. Much of this research training is acquired by doctoral students through co-authorship of articles with their supervisors. As argued by Kamler (2008), coauthorship is an important pedagogic practice that can enhance the robustness and know-how of doctoral scholars. Having addressed the critical feedback of supervisors, and included inputs of their supervisor in articles, most doctoral students are confident that the articles in question will survive rejection in prestigious journals in their field of research. Therefore, some doctoral students achieve their first international referred publication through co-authorship with their supervisors. As students mature in scholarly writing, some supervisors encourage them to submit some articles without their direct feedback or input in order to demonstrate academic independence. In some cases, students stop asking supervisors for feedback, and rather rely on reciprocal arrangement with peers to perform an internal reviewing function (Merga, 2015). Ultimately, the research training in $\mathrm{PBP}$ is expected to enable doctoral students to develop scholarly identity and carve a niche for themselves in their chosen field of research (Dowling et al., 2012; Merga, 2015). 
Lastly, it is argued that doctoral students who write PBP develop the resilience or the "thick skin" to cope with publication-related criticisms, anxiety, and depression. Irrespective of whether an article is submitted by a "novice" doctoral researcher as part of their PBP or not, most journals subject newly-submitted articles to the same publishing criteria of "criticality, extent of contextualization, impact, leading-edge, originality, rigour, scale, significance and topicality" (Badley, 2009). This implies that doctoral researchers are expected to argue, discuss and write like the experienced researchers in their field. Therefore, publishing in prestigious journals as part of PBP is a difficult target for most students. For every paper, journals, on the recommendation of their reviewers, decide either to reject or accept with revision. This decision is a major source of anxiety for most doctoral students, whether or not the article is co-authored with their supervisors (Jackson, 2013; Kamler, 2008). Furthermore, whether the manuscript is rejected or accepted subject to revision, editors and reviewers would normally provide constructive and critical feedback for the author to improve the paper for future submission. Rejection may be very depressing for most doctoral students, but embracing a resilient attitude is essential to enable them improve their work to a higher level (Merga, 2015). Journal rejection and the additional work needed to undertake resubmission elsewhere is a recurring issue in PBP (Merga et al., 2019). If papers are continuously accepted with revision, doctoral students have to regularly respond to feedbacks from several expert reviewers. In some cases, reviewers can be very harsh in their comments to authors, but the latter are expected to be calm and respond in a polite manner to the former. In this article, we will learn that addressing the feedback provided by journal editors and reviewers - a group that has received little acknowledgement in PBP studies - is equally a crucial part of the research training in PBP.

However, possessing the above-mentioned qualities does not completely imply success in one's $\mathrm{PhD}$ journey. Although $\mathrm{PhD}$ candidates take the lead in the research, decisions on what exactly to do, especially in the early stages, are often taken with supervisors. Reaching consensus between $\mathrm{PhD}$ students and supervisors can be a difficult task and, often, there are disagreements that take different forms. Such disagreements may impede the pace of the research or even lead to a halt in some circumstances. Gunnarsson et al. (2013) made a typology of the sources of disagreements between $\mathrm{PhD}$ candidates and supervisors which include, involvement in decision making, dubious suggestions from supervisors, supervisors not abreast with the work of the $\mathrm{PhD}$ candidate, interpersonal relationship and problems of mediating between multiple supervisors.

\section{Method}

This study adopts autoethnography as the research method. This method considers personal experiences as important sources of knowledge in and of itself, as well as a source of insight into the cultural experiences of people (Adams et al., 2015; Ellis \& Adams, 2014; Jones et al., 2013). In other words, it posits personal experiences as sources of data from which a social phenomena can be conceptualized (Prasad, 2019). As the name implies, it is believed that scholars combine and blend the usage of autobiography and ethnography characteristics to do autoethnography (Ellis et al., 2011). Therefore, autoethnography is both a process and a product. We adopted this method for a number of reasons: (1) autoethnography offers account of personal experiences to complement or 
fill in gaps about everyday experiences that cannot be captured through conventional research methods (2) autoethnography enables authors to articulate insider accounts of cultural experiences that other researchers may not be able to know, and (3) autoethnography creates simplified texts that are accessible and comprehensible to larger audience, especially those outside of academic settings (Adams et al., 2017).

Walford (2020) argues that there two broad ways of doing autoethnography: (1) writings by scholars about the research process, following publications about the substantive research (2) writings where the authors use their personal experiences of higher education to provide information about the nature of their educational experience. In this article, the two types overlap, as we draw on our research publications and educational experiences through the personal narrative approach, which entails stories about authors who consider themselves as the phenomenon of study and write evocative narratives about their academic, research and personal lives (Ellis et al., 2011; Walford, 2020). The question is: if autoethnography is personal and about self, then how can a study of self be carried out by two authors, as is the case in this article? To answer this question, we also adopted what Chang et al. (2013) call "collaborative autoethnography", which connotes a group of researchers pooling their everyday experiences to find commonalities and particularities and then revealing the meanings of these experiences in relation to their socio-cultural contexts.

Autoethnography has been criticized by the positivists for being self-indulgent, individualized and subjective and as such lacks reliability, validity and generalizability (Méndez, 2013). Likewise, some traditional ethnographers have sought to distance themselves from auto-ethnography. Walford (2020) for instance argues that the selfindulgence and individualism embedded in autoethnography do not meet ethnographic fundamentals of communicating something about others and, therefore, makes little or no contribution to knowledge. He further indicated that autoethnographic writings only appeal to persons who already know the author(s), a situation he likens to "sharing our [photograph] selfies with friends" (p. 10). However, we argue that such assertion lacks an understanding of the characteristics of autoethnography. On the basis of reliability, we believe that the personal narratives provided in this study is a true and credible reflection of our experiences, just as we accept the narratives of study participants as accurate description of a research problem. Therefore, if researchers can be trusted to accurately construct the views of study participants, then we can equally trust them to be truthful about their experiences of the research process and the nature of their doctoral studies. We, however, acknowledge that memory is fallible and so it is impossible to recall or report on our experiences in ways that reflect exactly how those experiences were lived and felt (Ellis et al., 2011). In the same manner, the data we gather during interviews may suffer the similar problem of participants' inability to recall everything. Our personal narratives are also valid because they evoke the feeling that the experiences are coherent, possible and believable. Seeing through an autoethnographic lens, we hold to the conviction that our experiences speak to those of other African doctoral students, and hence are generalizable to a considerable extent. It is important to note that we are not trained autoethnographers and so the text may not be written or structured as done by the professionals. Nevertheless, it must also be indicated that autoethnography has no specific rules to adhere to (Méndez, 2013), and hence we approached this article from a perspective that allows us to share our everyday experience of doing PBP. 
This article also aligns with post-colonial theoretical considerations in autoethnographic research (See Sobers, 2020). The colonial legacy is clearly manifest in the manner in which majority of the so-called international journals are not only based in Western countries, but are also mostly headed by editors-in-chief from the West. What is more, research produced by African researchers is either perceived to be poorly written or based on data that cannot be trusted. As African students studying in European universities, we construct our proximity to our Western supervisors (some of whom are editors and reviewers and may have rejected papers written by African scholars) as an excellent opportunity to challenge the existing notion that Africans produce low-quality research. Through auto-ethnography, we are able to communicate how it feels to be an African pursuing PBP, which measures high-quality publications as success.

\section{The biography, motivation and experiences of the authors}

\section{Brief biography of authors}

Lewis, the first author, has recently completed his $\mathrm{PhD}$ at Humboldt-Universitat zu Berlin in Germany. He holds a Bachelor's degree from the Kwame Nkrumah University of Science and Technology in Ghana and a Master's degree from the London School of Economics and Political Science in England. Upon completion of his master's degree, he worked as a Lecturer at the Kumasi Technical University for 4 years. He started his doctoral studies in October 2016 and submitted the doctoral dissertation in October 2019. His doctoral research falls within the scope of urban regeneration, market redevelopment, urban governance and political economy in Africa. His research has one main question and five sub questions. Each of the five sub-questions was developed into an article. Four out of the five articles in his doctoral dissertation were published prior to submission while the remaining one is a revised manuscript under review. Aside the five articles in his dissertation, Lewis has also published four articles from October 2016 to date.

Zaid, the second author, is currently a doctoral student at the University of Twente, the Netherlands. He holds a Bachelor's degree from the Kwame Nkrumah University of Science and Technology in Ghana and a Master's degree from the University of Twente in the Netherlands. After completing the master's degree, he worked as an Assistant Land Administration Officer at the Lands Commission in Ghana for 3 years. He started his doctoral studies in August 2016 and has submitted his doctoral dissertation in July, 2020. His research focuses on how socio-cultural practices of land inheritance influence the updating of the land register. The research has one main question and four sub questions. So far, three articles have been published out of the four sub questions. Aside the three articles of the PhD, Zaid has also published five other articles between 2016 and 2019.

\section{Motivation for the PBP pathway}

As indicated in our profiles, we had different professional backgrounds and research experience prior to our candidature. Our backgrounds reflect two groups of African doctoral students: those who struggled with journal article publishing at the highest level, and those whose publication was crucial in securing a $\mathrm{PhD}$ position. We will also learn 
that the nature of the $\mathrm{PhD}$ position determines whether an individual has the option to choose the PBP pathway or not.

\section{Lewis Abedi Asante}

I started teaching at Kumasi Polytechnic (now Kumasi Technical University) in October 2012, about 9 months after I had acquired my MSc degree in the United Kingdom. During the masters programme, I had read a lot of interesting and thoughtprovoking journal articles and I wished I could one day put my ideas on paper in the same manner. When I became a polytechnic lecturer, I started trying my hands on publishing a few articles in highly rated international journals such as Housing Studies, Cities and Land Use Policy. In all cases, my manuscripts were rejected with a long list of reviewer comments. Several colleagues in my department faced similar rejections. Perhaps, Tarkang and Bain (2019) were right to have argued that majority of manuscripts rejected by international journals are submitted by African scholars. But I noticed certain things from the comments that I received from the journals: the introduction was not convincing and did not clearly indicate the contribution of the paper; the literature and methodological discussions were quite superficial; the analysis of the findings lacked depth; the conclusion was just a summary of the other sections and did not discuss the wider implications of the findings; and the writing style was relatively immature.

Obviously, my manuscripts did not meet the empirical, methodological and theoretical standards of the journals in question. Although the consistent rejections were discouraging, perhaps, what I may not have noticed during this period, was that I was nurturing my writing skills through the persistent submission of articles to highly rated journals and improving articles based on the review comments. Notably, one of the major requirements for promotion from the position of lecturer to senior lecturer in my polytechnic was four publications in peer-reviewed journals. Nevertheless, after 4 years of working as a polytechnic lecturer and having met almost every other requirement for promotion, I had co-authored only one publication in an international journal, specifically Sage Open (See Ehwi \& Asante, 2016). By implication, I had to improve my publication record or perish at the lecturer position for many years. Moreover, by 2016, the Government of Ghana had passed a law to convert all polytechnics into technical universities. This conversion was accompanied by not only a modification of the minimum entry requirement for teaching position from masters degree to $\mathrm{PhD}$, but also enhanced promotion requirements from four to six publications. Existing staffs were given a period of time to upgrade, otherwise they would be phased out of the system.

Fortunately, in October 2016, I successfully secured full funding to pursue a $\mathrm{PhD}$ in Geography in a German university, with the liberty to write a monograph or PBP. I had two main motives for undertaking the $\mathrm{PhD}$ : one was to retain my teaching appointment with the technical university, and the other was to acquire the relevant research skills and training to ask critical research questions, gather in-depth research data and write journal articles that are capable of being published in prestigious international journals. The decision to study in Germany was informed by several conversations with senior colleagues, whose publication records had shot up significantly through the PBP pathway in German universities. Therefore, when my supervisor accepted to supervise my doctoral research, I clearly indicated to her that I would like to take the PBP pathway. Although she had no previous experience of supervising PBP, nor an African doctoral 
student, she accepted the challenge. Today, I consider my $\mathrm{PhD}$ qualification as serving a two-pronged purpose of securing my employment and equipping me with the skill and experience I need to progress in my chosen professional career, contribute significantly to the empirical and theoretical debates in my field of urban and human geography and proffer crucial solutions to the emerging urban problems in Ghana and beyond.

\section{Zaid Abubakari}

I have heard the statement "publish or perish" countless times from academics, especially lecturers, since the undergraduate level. At the early stages, I was curious to understand what the statement actually meant. But as I progressed in my academic ladder I started to really appreciate the good things that good publications do, and can do, for academics, as well as countries and society more generally. I had a glimpse of this feeling when I had my very first paper published based on my MSc thesis in Land Use Policy (See Abubakari et al., 2016). Soon after the publication, I got an invitation to present it at the 2016 Symposium on Land Consolidation and Land Readjustment in the Netherlands. The publication among other things also strengthened my application for a $\mathrm{PhD}$ position in the same university I completed my masters' degree. Unlike Lewis, my $\mathrm{PhD}$ position had the requirement of PBP, so I did not have much choice in taking a decision. This kind of mandatory requirement is what led Frick (2019) to ask if students' interest is primary in PBP.

Having benefitted this much from my first publication, it became apparent to me that publishing does not only enable me to grow academically, but also allows me to share my ideas with a wider audience. Pursuing PBP was therefore an opportunity to learn to become a good academic, to share my ideas with a global audience and to enhance my problem-solving orientation. Having to ask and address a valid research question in each publication makes me more diligent in identifying and analyzing real societal problems in Ghana. Directly, PBP has shaped my academic trajectory and at the same time, enabled me to contribute to national development through my research work. With PBP, I do not only meet the entry requirement for teaching position in a Ghanaian or foreign university but also possess a good number of articles that qualifies me to progress within the shortest possible time.

\section{Publication-based dissertation: our experiences}

Following the tenets of collaborative autoethnography, we pool together our experiences to provide insights into how African doctoral students experience PBP. Right from the beginning of our PhDs, we had different entry options. While Lewis had the options of a monograph or PBP pathway, Zaid had to follow the PBP pathway; but in the end Lewis also chose the PBP pathway. Generally, our universities require doctoral candidates to produce a dissertation that contained at least three to four articles, some of which must be published and some under review in peer-reviewed journals listed in Science Citation Index (ISI) and SCOPUS which are pertinent and relevant to the field of geography. However, Lewis' university requires a minimum of one publication prior to submission, while Zaid was expected to publish a minimum of two articles. While our universities encourage doctoral candidates to produce single-authored articles, where articles are co-authored, the doctoral students must either be the main author 
or must have contributed significantly to the articles. Both of us co-authored all articles in our dissertations with our supervisors.

The journey to publishing is one that is both difficult and time consuming, and thus requires a significant amount of skill and perseverance to traverse. Although each of us had published a paper before starting our PhD studies, we did not feel overly confident of our analytical and writing skills. To enhance these skills, we carefully studied the writing and argument structure of many scholars and noted the rudiments of key sections of scientific work. This process was particularly crucial for Lewis, whose pre-PhD papers were rejected for weakness in many aspects. In addition to this, Zaid took courses on academic writing at different universities. As the research work progressed, we sharpened our scholarly writing skill by co-authoring articles outside of our $\mathrm{PhD}$ works. Through such external collaborations, the first author successfully published in Geojournal and Sage Open (See Asante \& Sasu, 2018; Asante et al., 2018, 2017) while the second author also published in geography journals such as Climate Services, Land and Cities (See Ahmed et al., 2020; Naab et al., 2019; Salifu et al., 2019). Thus, collaborations outside one's PhD study plays a significant role in one's academic development, and helps to diversify one's academic experience.

Additionally, beginning the academic journey by writing and publishing a review paper helps to quickly sharpen one's skills and familiarize oneself with the literature. What is more, review articles require more work than empirical ones because the secondary data have to be innovatively discussed and conceptualized to show clear theoretical contribution. Therefore, if one is able to successfully publish a review article, it would be relatively less difficult to publish an empirical research. Furthermore, writing review articles provide an early opportunity to collaborate with one's supervisor on a first paper, to understand their perspectives on the theme of the research, and to strike consensus on subjects of possible internal disagreements. In this respect, Lewis published a review article in the Canadian Journal of African Studies (See Asante \& Helbrecht, 2018) while Zaid made a conference presentation on a systematic literature review during the Landac 2018 conference (See Abubakari, 2018). Having successfully published before and during the $\mathrm{PhD}$, we became more confident about our scholarly writing skills and felt very ready to start putting together articles for the $\mathrm{PhD}$ work. This was the game changer for both of us.

Co-authoring paper after paper with our supervisor(s) was tough research training for us. In the beginning of the $\mathrm{PhD}$, we relied heavily on the guidance of our supervisors. When we started putting together our first papers, it was really a cumbersome process and required lots of meetings and series of reviews. Although the process was tough, it set the stage for us to build on the experience as the $\mathrm{PhD}$ progressed. The subsequent papers were relatively less difficult to put together. The experience increased the ease of writing and responding to reviewer comments; however, every paper came with its own set of challenges during the conceptual, writing or review stages. Although our supervisors sometimes noticed our fatigue, they regularly gave encouragement for the success of the work. Both of us had supervisors who were particularly supportive in providing timely, constructive and critical comments, as well as relevant inputs to enrich the content of write-ups prior to submission to journals. The choice of journal was an important recurring issue during the $\mathrm{PhD}$ training. As Africans, we were willing to challenge ourselves by submitting articles to high-impact journals such as Geoforum and Urban 
Geography, although this decision was mostly taken with our supervisors. Whereas our experiences of the PBP pathway as African students may not differ from PhD students of other origins, our unique experience lies in how far the PBP has transformed us, given our weak background. For example, even as Lewis was lecturing before his candidature, he hardly could succeed in publishing. But in a span of three years of PBP, he has now published more than six articles.

The research training extended to how reviewer comments were addressed. When reviewers provided comments on papers, it was our sole responsibility to first address all the comments. Review comments came through at the time when the write-up of other papers were ongoing. This meant the ongoing write-ups had to be put on hold in order to concentrate on the revision of papers under review. Addressing review comments sometimes required further reading and data analysis, but we did our best to respond to all of them within the period of revision provided by journal editors. Afterwards, the supervisors reviewed the revised manuscript against the reviewer comments to ensure that all comments have been adequately addressed. In most cases, our supervisors were happy with the clarity and depth of responses to the review comments. Therefore, it is not surprising that we both did a maximum of two revisions on all papers in our dissertation. The comments of reviewers sometimes varied considerably on the same paper and can really be confusing for doctoral students as to what to do. Sometimes, we found the comments of reviewers to be very constructive and well founded, but other times we found them quite remote, harsh and unfounded. There were times we thought some journal reviewers clearly displayed lack of deeper understanding of the African context, and were quick to question our application of some theories or concepts. Whatever the case may be, we still tried to respond in the best and polite manner. Internal conflicts and disagreements between us and our supervisors were very minimal, as we had consensus for the most part.

The most pleasant moment of the publication process for us as Africans is when we received mails from the editors that our papers have been accepted for publication. It felt extremely good to be contributing to knowledge production at the highest level. However, before this pleasant moment arrives, a series of unpleasant things like a delay in getting reviewer comments, "not-so-good" reviewer comments and even rejection does happen. For instance, Lewis faced two rejections with paper submissions in the International Journal of Urban and Regional Research, and Development and Change. Journal rejections brought unpleasant moments and built a lot of anxiety and lowspiritedness. For Lewis, such rejections brought back memories of pre-PhD experiences in Ghana; but strangely he realized that his supervisor was equally affected emotionally, having approved submission. One of these papers was subsequently reworked and got published in Geoforum. From this experience, we have come to the realization that journal rejections are a normal practice in scholarly development, and should be constructed as an opportunity to improve on the content of the paper for submission elsewhere and not necessarily because the papers may have originated or is about a subject matter in Africa.

We may have regarded journal editors and reviewers as "troublesome", and sometimes "annoying", when rejections and harsh comments were received, but their contribution in PBP cannot be underestimated. They are the "invisible" mentors whose constructive comments significantly improve the content of every published paper in a publication- 
based thesis, albeit the original focus of the papers may change. Specifically, they raise issues we and our supervisors may have overlooked or never thought about. Sometimes, they suggested existing publications that helped us to better situate our papers in the discourse. We argue that, in PBP, the more articles that are subjected to journal peerreview, the stronger the overall thesis become. The reverse may be true. Therefore, doctoral students who make a first or second publication early in the PhD should not be in a hurry to submit their dissertation but should exhaust the full period of the $\mathrm{PhD}$ position, as additional publications will strengthen the final output. Unlike the traditional monograph $\mathrm{PhD}$ with one oral examination at the end, we argue that doctoral students who pursue $\mathrm{PBP}$ are subjected to multiple examinations through responses to journal editors and reviewers and to examiners during the oral defense. Likewise, doctoral students who have had to regularly respond to reviewer comments through the peerreview process of journals are likely to be more confident during the oral defense than those who write monograph. In a nutshell, journal editors and reviewers may make us depressed through their comments and decisions, but it is also through them that the exciting times come.

Another fulfilling moment after a paper gets published is when it gets cited and widely read. It is joy to see the metrics of one's publication rise on ResearchGate, Google Scholar or Scopus. It gives a feeling that the information in the paper is beneficial to others, although the reverse could be true as well. Prior to submission of his $\mathrm{PhD}$ dissertation, Lewis had published four articles in geography journals such as Urban Geography, Geojournal and Journal of Urban Affairs (See Asante \& Helbrecht, 2020, 2019a, 2019c, 2019b). Zaid has also published three PhD-related articles in journals such as Land Use Policy, Geoforum and Sustainability (Abubakari et al., 2018, 2019, 2020). To demonstrate the success of the academic training, Lewis has written a single-authored article and published same in African Geographical Review (See Asante, 2020) and has started reviving all the papers that were rejected prior to his PhD study. One of such papers is now published with Sage Open (See Asante \& Sasu, 2018) and another is a revised manuscript currently under review in Housing Studies.

The substantial shift in our publication derives from the skills that we have gained by pursuing PBP. One, we have developed the writing skill to present and discuss each aspect of an article in an analytical way and with a high level of rigour. Two, we have become more conversant with the theories and concepts in our field of expertise and are able to identify gaps that contribute to what we already know about them. Three, the independence to respond to review comments is also very important skill we value. Through our publications, we are gradually becoming visible in the fields of urban regeneration and governance, as well as land administration and governance in Africa. The visibility has even become more pronounced through financial support from our universities for our articles to be published open access. We have also become journal reviewers due to the consistent publication in our field of research. Together, we have reviewed articles for top-rated international journals such as Housing Studies, Survey Review, International Development Planning Review, Habitat International, African Geographical Review and Land Use Policy. At this moment, we feel we can contribute to local, national and global research and development. As citizens of an African country, publishing affords us the opportunity to increase the number of publications from Africa and to document observed local problems, analyse them and draw cues from similar 
contexts elsewhere to suggest solutions for policy makers and frontline implementers. Essentially, our publications are a part of a much bigger scientific platform, that gives others the opportunity to learn and contribute to local and global development.

\section{Discussion}

In this section, we briefly discuss how our experiences of PBP compare with other doctoral students who have shared their experiences. Generally, the requirements of PBP are similar in many universities around the globe, albeit with slight differences regarding the number of articles that must be published prior to completion (Jackson, 2013; Lee, 2010; Merga, 2015; Robins \& Kanowski, 2008) and whether or not the PBP is retrospective, in which case previous publications before candidature can be considered as part of the $\mathrm{PhD}$ thesis or prospective, when previous publications before candidature are not considered as part of the PhD thesis (Davies \& Rolfe, 2009; Jackson, 2013). Both of us had only the option of a prospective PBP, since we did not have any previous publication on the PhD topics. We believe that our university requirements, like what Mason (2018) experienced in Griffith University, were relatively achievable and less stressful with a period of 4 years, and not as burdensome as the practice at the University of Pretoria (Pretorius, 2017).

Also, scholarly writing skills and experience required to meet these requirements differ from one doctoral candidate to another depending on their previous training and academic engagements. Whereas it appears relatively easy for those with a good amount of experience to pursue PBP, it can be daunting for the novice (Davies \& Rolfe, 2009; Smith, 2017). Interestingly, we observed from our experiences and the literature that, irrespective of one's previous publication experiences and its associated scholarly writing skills, there is usually some self-doubt and lack of confidence about its adequacy for successful completion of PBP (Merga, 2015; Niven \& Grant, 2012). For example, although each of us had published before our candidature, putting together the first publication was very challenging for us and we found similar experiences with other $\mathrm{PhD}$ students, as shown in the work of Dowling et al. (2012). This feeling of inadequacy makes doctoral students determined to sharpen and improve their scholarly writing skills through institutional, supervisory and external support systems. We contend that these support systems are critically essential throughout the period of the PBP.

Moreover, PBP enables one to develop skills required for an academic career and a publication record that enhances competitiveness in a tight academic job market (Dowling et al., 2012). From our experiences, we testify to this assertion as the first author through his PBP pathway got enough publications which enable him to keep his university job and also meet requirement for promotion to senior lecturer position. This is in consonance with the South African experience as noted by Pretorius (2017) where publications serve as the benchmark for academic promotions and securing research funding. A similar experience is shared in the study of Davies and Rolfe (2009) for the UK. More importantly, in recent times, online academic platforms such as Researchgate enhance the potential of $\mathrm{PhD}$ candidates by making their publications more visible to a worldwide audience and particularly to the academic community.

Furthermore, based on our experiences, we totally agree with Urda-Cîmpean et al. (2016) that PBP is focused on research training for doctoral students in the areas of 
collaborating with other researchers in writing articles, dealing with critical appraisal from blinded journal reviewers and acquiring the abilities needed for scientific article production. Collaborations provide doctoral researchers with valuable experiences for teamwork, interdisciplinarity and also increases the visibility of the work of the doctoral researcher through multiple networks of co-authors (Davies \& Rolfe, 2009; Dowling et al., 2012). More importantly, we believe that this is the level of research training that is required to equip African scholars to champion and increase knowledge production at the highest level of academia (Amavilah, 2009; Asongu \& Nwachukwu, 2018). This collaborative aspect of PBP links back to its potential of enhancing one's academic visibility and positioning in the job market.

Finally, although we value the PBP pathway, we do not seek to claim its perfection; it has its own challenges. We have both experienced delays in review and journal response during the publication process (Jackson, 2013). For example, the last chapter of Lewis' thesis took more than a year to get published. Having acknowledged this impediment, $\mathrm{PhD}$ students often have to adapt their research timetable to the temporal rhythms of the review process, which in itself creates instability in the overall research timings (Dowling et al., 2012; Merga et al., 2019).

\section{Concluding remarks}

While many doctoral students have shared their experiences of PBP in the recent past, the voice of African students has been relatively low in this emerging discourse. This study adopted collaborative autoethnography to understand the motivation and everyday experiences of two African doctoral students who took the PBP pathway. We have demonstrated that the motivation for pursuing PBP could differ depending on the predoctoral professional background and research experience of students and the nature of their $\mathrm{PhD}$ positions. However, the common motivation among African doctoral students is the quest to acquire the relevant research skill and training in publishing journal articles. We believe that an increase in scientific publication through PBP will gradually diminish or reduce the application of northern theories, and project the development of African-based concepts to analyze and understand African problems. PBP has the potential to illuminate the emerging field of southern urbanism in the field of urban planning and geography, where new concepts and theories begin to emerge from the context of the global south (Schindler, 2017). Lewis, for instance, adopted an African conceptualization of urban governance in all his articles to analyze the dynamics at different phases of market redevelopment in Ghana.

This article has also shown that the everyday experiences of African doctoral students do not necessarily differ from colleagues from other parts of the world. PBP requirements are similar across many universities. While students may not possess the same level of scholarly writing skills at the start of their $\mathrm{PhD}$, they are expected to develop the same skill through the institutional, supervisory and external support systems. Through PBP, doctoral students are also subjected to similar research training in the art of developing relevant research ideas and questions, writing journal articles and responding to thoughtprovoking reviewer comments. Nevertheless, the point of departure is that African doctoral students navigate the PBP pathway with the mindset of catching-up with the 
rest of the world in the knowledge economy through the production of high-quality scientific publications (Asongu \& Nwachukwu, 2018).

PBP has numerous positive implications for educational and socio-economic development in Africa. On the educational front, African universities would be staffed by scholars who engage in discourses on cutting edge research and whose publications appear in the international scientific space. Also, through publications, universities and departments could attract funding for research and to start new academic programmes. This has the potential of providing African students a formidable foundation in research and development across different levels of geography education. Additionally, regular publications would improve the ranking of African universities in the world university rankings (Davies \& Rolfe, 2009; Kamler, 2008). In terms of socio-economic development, cutting edge scholarly work with local relevance lends itself more for policy making and implementation of both national and sub-national development projects. Moreover, scholars with regular publications are able to secure funding to translate their research into community projects that benefit the local people. These potential benefits of PBP cut across different country contexts in Africa. In the case of South Africa, Frick (2016), Pretorius (2017) and Gumbo (2017) argued that sustainable development is underpinned by the production of highly trained people, including $\mathrm{PhD}$ students, who engage in high-quality research. In a more generalized way, Asongu and Nwachukwu (2018) argued that PBP is one of the best ways African countries can bridge the knowledge gap between them and their western counterparts and that PBP can enhance, considerably, technology transfer and innovation in Africa.

Based on our experiences, we are of the opinion that journals should have dedicated peer-review process for doctoral students. A good example is the Scholar Development Program of the Journal of Urban Affairs. Through such a program, journals can assign editors to $\mathrm{PhD}$ students to point out the weakness of their papers and to provide individual guidance on how to improve those papers. This additional external support system is extremely crucial for African doctoral students in their PBP journey.

\section{Disclosure statement}

No potential conflict of interest was reported by the authors.

\section{ORCID}

Lewis Abedi Asante (D) http://orcid.org/0000-0002-5485-8489

\section{References}

Abubakari, Z. (2018). Is conventional never Innovative? An analysis of the discourse around land tenure documentation. https://www.researchgate.net/publication/326816082_Is_Conventional_ never_innovative_an_analysis_of_the_discourses_around_land_tenure_documentation 
Abubakari, Z., Richter, C., \& Zevenbergen, J. (2018). Exploring the “implementation gap" in land registration: How it happens that Ghana's official registry contains mainly leaseholds. Land Use Policy, 78, 539-554. https://doi.org/10.1016/j.landusepol.2018.07.011

Abubakari, Z., Richter, C., \& Zevenbergen, J. (2019). Plural Inheritance laws, practices and emergent types of property: implications for updating the land register. Sustainability, 11 (6087), 1-17. https://doi.org/10.3390/su11216087

Abubakari, Z., Richter, C., \& Zevenbergen, J. (2020). Making space legible across three normative frames: The (non-)registration of inherited land in Ghana. Geoforum, 108, 217-226. https://doi. org/10.1016/j.geoforum.2019.11.002

Abubakari, Z., van der Molen, P., Bennett, R. M., \& Kuusaana, E. D. (2016). Land consolidation, customary lands, and Ghana's Northern Savannah Ecological Zone: An evaluation of the possibilities and pitfalls. Land Use Policy, 54, 386-398. https://doi.org/10.1016/j.landusepol. 2016.02.033

Adams, T. E., Ellis, C., \& Jones, S. H. (2017). Autoethnography. In J. Matthes (Ed.), The international encyclopedia of communication research methods (pp. 1-11). John Wiley \& Sons Inc. https://onlinelibrary.wiley.com/doi/pdf/10.1002/9781118901731.iecrm0011

Adams, T. E., Jones, S. H., \& Ellis, C. (2015). Autoethnography: Understanding qualitative research. Oxford University Press.

Ahmed, A., Korah, P. I., Dongzagla, A., Nunbogu, A. M., Niminga-Beka, R., Kuusaana, E. D., \& Abubakari, Z. (2020). City profile: Wa, Ghana. Cities, 97, 1-14. https://doi.org/10.1016/j.cities. 2019.102524

Amavilah, V. H. S. (2009). Knowledge of African countries: Production and value of doctoral dissertations. Applied Economics, 41(8), 977-989. https://doi.org/10.1080/ 00036840601019117

Asante, L. A. (2020). Urban governance in Ghana: The participation of traders in the redevelopment of Kotokuraba Market in Cape Coast. African Geographical Review, 1-18. https://doi.org/ $10.1080 / 19376812.2020 .1726193$

Asante, L. A., Gavu, E. K., Quansah, D. P. O., \& Osei Tutu, D. (2018). The difficult combination of renting and building a house in urban Ghana: Analysing the perception of low and middle income earners in Accra. GeoJournal, 83(6), 1223-1237. https://doi.org/10.1007/s10708-0179827-2

Asante, L. A., \& Helbrecht, I. (2018). Seeing through African protest logics: A longitudinal review of continuity and change in protests in Ghana. Canadian Journal of African Studies/Revue Canadienne Des Études Africaines, 52(2), 159-181. https://doi.org/10.1080/00083968.2018. 1477607

Asante, L. A., \& Helbrecht, I. (2019a). Changing urban governance in Ghana: The role of resistance practices and activism in Kumasi. Urban Geography, 40(10),1-28. https://doi.org/10.1080/ 02723638.2019.1631109

Asante, L. A., \& Helbrecht, I. (2019b). The urban dimension of Chinese infrastructure finance in Africa: A case of the Kotokuraba Market Project, Cape Coast, Ghana. Journal of Urban Affairs, 1-21. https://doi.org/10.1080/07352166.2019.1629819

Asante, L. A., \& Helbrecht, I. (2019c). Urban governance and its implications for the microgeographies of market trading in Ghana: A case of the Kotokuraba Market Project in Cape Coast. GeoJournal, 1-23. https://doi.org/10.1007/s10708-019-10018-0

Asante, L. A., Quansah, D. P. O., Ayitey, J., \& Kuusaana, E. D. (2017). The practice of defect liability period in the real estate industry in Ghana. SAGE Open, 7(3), 1-15. https://doi.org/10. 1177/2158244017727038

Asante, L. A., \& Sasu, A. (2018). The challenge of reducing the incidence of building collapse in Ghana: Analyzing the perspectives of building inspectors in Kumasi. SAGE Open, 8(2), 1-12. https://doi.org/10.1177/2158244018778109

Asante, L.A. \& Helbrecht, I. (2020). Conceptualising marketplaces in Anglophone West Africa: A sexpartite framework, 85(1), 221-236. 
Asongu, S. A., \& Nwachukwu, J. C. (2018). PhD by publication as an argument for innovation and technology transfer: With emphasis on Africa. Higher Education Quarterly, 72(1), 15-28. https://doi.org/10.1111/hequ.12141

Badley, G. (2009). Publish and be doctor-rated: The PhD by published work. Quality Assurance in Education, 17(4), 331-342. https://doi.org/10.1108/09684880910992313

Carr, N., \& Hayes, S. (2017). A comparison of tourism PhD Students' publication records and university of study. Tourism Management Perspectives, 23, 151-153. https://doi.org/10.1016/j. tmp.2017.06.005

Chang, H., Ngunjiri, F. W., \& Hernandez, K.-A. C. (2013). Collaborative autoethnography. Left Coast Press, Inc.

Connor, T. (2016). PhD by publication. In C. Ashford \& J. Guth (Eds.), The legal academic's handbook (pp. 28-30). Palgrave Macmillan.

Davies, R. E., \& Rolfe, G. (2009). PhD by publication: A prospective as well as retrospective award? Some subversive thoughts. Nurse Education Today, 29(6), 590-594. https://doi.org/10.1016/j. nedt.2009.01.006

Dowling, R., Gorman-Murray, A., Power, E., \& Luzia, K. (2012). Critical reflections on doctoral research and supervision in human geography: The "PhD by publication". Journal of Geography in Higher Education, 36(2), 293-305. https://doi.org/10.1080/03098265.2011.638368

Ehwi, R. J., \& Asante, L. A. (2016). Ex-post analysis of land title registration in ghana since 2008 merger: Accra lands commission in perspective. SAGE Open, 6(2), 215824401664335. https:// doi.org/10.1177/2158244016643351

Eigi, J. (2013). "Knowing things in common": Sheila jasanoff and helen longino on the social nature of knowledge. Acta Baltica Historiae Et Philosophiae Scientiarum, 1(2), 26-37. https:// doi.org/10.11590/abhps.2013.2.03

Ellis, C., \& Adams, T. E. (2014). The purposes, practices and principles of autoethnographic research. In P. Leavy (Ed.), The oxford handbook of qualitative research (pp. 254-276). Oxford University Press.

Ellis, C., Adams, T. E., \& Bochner, A. P. (2011). Autoethnography: An overview. Forum: Qualitative Social Research, 12(1), 1-14. www.qualitative-research.net/index.php/fqs/article/ view/1589/0

Frick, L. (2016). PhD by publication: An institutional analysis. In M. Fourie-Malherbe, C. Aitchison, E. Blitzer, \& R. Albertyn (Eds.), Postgraduate supervision - Future foci for the knowledge society (pp. 299-312). SUN Press.

Frick, L. (2019). PhD by publication - Panacea or paralysis? Africa Education Review, 16(5), 47-59. https://doi.org/10.1080/18146627.2017.1340802

Gumbo, J. A. (2017). PhD by Publication or PhD by Traditional Model : Which Way to Go? In The 2nd Annual International Conference on Public Administration and Development Alternatives (pp. 164-168). Gaborone, Botswana.

Gunnarsson, R., Jonasson, G., \& Billhult, A. (2013). The experience of disagreement between students and supervisors in PhD education: A qualitative study. BMC Medical Education, 13(1), 134. https://doi.org/10.1186/1472-6920-13-134

Horta, H., \& Santos, J. M. (2016). The Impact of publishing during PhD studies on career research publication, visibility, and collaboration. Research in Higher Education, 57(1), 28-50. https:// doi.org/10.1007/s11162-015-9380-0

Jackson, D. (2013). Completing a PhD by publication: A review of Australian policy and implications for practice. Higher Education Research and Development, 32(3), 355-368. https://doi.org/ 10.1080/07294360.2012.692666

Jones, S. H., Adams, T. E., \& Ellis, C. (2013). Handbook of autoethnography. Routledge.

Kamler, B. (2008). Rethinking doctoral publication practices: Writing from and beyond the thesis. Studies in Higher Education, 33(3), 283-294. https://doi.org/10.1080/03075070802049236

Lee, A. (2010). When the article is the dissertation: Pedagogies for a $\mathrm{PhD}$ by publication. In C. Aitchison, B. Kamler, \& A. Lee (Eds.), Publishing pedagogies for the doctorate and beyond (pp. 12-29). Routledge. 
Lee, A., \& Kamler, B. (2008). Bringing pedagogy to doctoral publishing. Teaching in Higher Education, 13(5), 511-523. https://doi.org/10.1080/13562510802334723

Mason, S. (2018). Publications in the doctoral thesis: Challenges for doctoral candidates, supervisors, examiners and administrators. Higher Education Research and Development, 37(6), 1231-1244. https://doi.org/10.1080/07294360.2018.1462307

Méndez, M. G. (2013). Autoethnography as a research method: Advantages, limitations and criticisms. Colombian Applied Linguistics Journal, 15(2), 279-287. https://doi.org/10.14483/ udistrital.jour.calj.2013.2.a09

Merga, M. K. (2015). Thesis by publication in education: An autoethnographic perspective for educational researchers. Issues in Educational Research, 25(3), 291-308.

Merga, M. K., Mason, S., \& Morris, J. E. (2019). 'What do I even call this?': Challenges and possibilities of undertaking a thesis by publication. Journal of Further and Higher Education, 1-17. https://doi.org/10.1080/0309877X.2019.1671964

Naab, F. Z., Abubakari, Z., \& Ahmed, A. (2019). The role of climate services in agricultural productivity in Ghana: The perspectives of farmers and institutions. Climate Services, 13, 24-32. https://doi.org/10.1016/j.cliser.2019.01.007

Niven, P., \& Grant, C. (2012). PhDs by publications: An "easy way out"? Teaching in Higher Education, 17(1), 105-111. https://doi.org/10.1080/13562517.2012.640086

O'Keeffe, P. (2020). PhD by publication: Innovative approach to social science research, or operationalisation of the doctoral student ... or both? Higher Education Research and Development, 39(2), 288-301. https://doi.org/10.1080/07294360.2019.1666258

Peacock, S. (2017). The PhD by Publication. International Journal of Doctoral Studies, 12, 123-135. https://doi.org/10.28945/3781

Prasad, A. (2019). Autoethnography and organisation research: Reflections from fieldwork in palestine. Palgrave Macmillan.

Pretorius, M. (2017). Paper-based theses as the silver bullet for increased research outputs: First hear my story as a supervisor outputs. Higher Education Research and Development, 36(4), 823-837. https://doi.org/10.1080/07294360.2016.1208639

Robins, L., \& Kanowski, P. (2008). PhD by publication: A student perspective. Journal of Research Practice, 4(2), 1-20. http://go.galegroup.com/ps/anonymous?id=GALE\%7CA168070793\&sid= googleScholar\&v=2.1\&it $=\mathrm{r} \&$ linkaccess $=\mathrm{abs} \&=00384348 \& \mathrm{p}=\mathrm{AONE} \& \mathrm{sw}=\mathrm{w}$

Salifu, F. W., Abubakari, Z., \& Richter, C. (2019). Innovating along the continuum of land rights recognition: Meridia's "Documentation packages” for Ghana. Land, 8(12), 1-18. https://doi. org/10.3390/LAND8120189

Schindler, S. (2017). Towards a paradigm of Southern urbanism. City, 21(1), 47-64. https://doi. org/10.1080/13604813.2016.1263494

Sharmini, S., \& Kumar, V. (2018). Examiners' commentary on thesis with publications. Innovations in Education and Teaching International, 55(6), 672-682. https://doi.org/10.1080/ 14703297.2017.1294491

Sharmini, S., Spronken-Smith, R., Golding, C., \& Harland, T. (2015). Assessing the doctoral thesis when it includes published work. Assessment \& Evaluation in Higher Education, 40(1), 89-102. https://doi.org/10.1080/02602938.2014.888535

Sigler, T., Lieske, S. N., Charles-Edwards, E., \& Corcoran, J. (2018). Why do a PhD in geography? A sympathetic response to 'the career aspirations and expectations of geography students. Geographical Research, 56(4), 479-483. https://doi.org/10.1111/1745-5871.12307

Smith, S. (2017). Supervising on a PhD by Published Work route: An exploration of the supervisory role. Zeitschrift Fur Hochschulentwicklung (Journal for Higher Education Development), 12(2), 19-43.

Sobers, S. (2020). Colonial complexity in the British landscape: An african centric authethnography. In S. De Nardi, H. Orange, S. High, \& E. Koskinen-Koivisto (Eds.), The routledge handbook of memory and place (pp. 42-51). Routledge.

Tarkang, E. E., \& Bain, L. E. (2019). The bane of publishing a research article in international journals by African researchers, the peer-review process and the contentious issue of predatory 
journals: A commentary. The Pan African Medical Journal, 32(119), 1-5. https://doi.org/10. 11604/pamj.2019.32.119.18351

Urda-Cîmpean, A. E., Bolboac, S. D., Achima-Cadariu, A., \& Drugan, T. C. (2016). Knowledge production in two types of medical $\mathrm{PhD}$ routes - What's to gain? Publications, 4(14), 1-16. https://doi.org/10.3390/publications 4020014

Walford, G. (2020). What is worthwhile auto-ethnography? Research in the age of the selfie. Ethnography and Education, 1-13. https://doi.org/10.1080/17457823.2020.1716263

Watts, J. (2012). To publish or not to publish before submission? Considerations for doctoral students and supervisors. Creative Education, 3(1), 1101-1107. https://doi.org/10.7459/ept/35.1.05 